\title{
Otimização da Extração de Carotenoides Totais e Determinação da Capacidade Antioxidante em Melancia de Polpa Amarela.
}

\author{
Sara P. Castro*, Letícia C. da Silva, Lívia S. Constant, Helena T. Godoy
}

\section{Resumo}

A melancia é uma fruta muito consumida devido às suas características sensoriais de refrescância e doçura. Existem melancias cujas polpas possuem outras colorações, além da avermelhada, como a amarela e que ainda carecem de informações, uma vez que também podem ser fonte de compostos bioativos capazes de promover benefícios à saúde. O objetivo deste trabalho foi otimizar a extração sólido-líquido dos carotenoides totais da melancia de polpa amarela e avaliar a capacidade antioxidante do extrato otimizado. O estudo estabelece condições otimizadas para a extração sólido-líquido de compostos fenólicos totais utilizando delineamento composto central e uma posterior cinética. A concentração de carotenoides totais variou de 5,25 a $37,49 \mu \mathrm{g} / \mathrm{g}$ e avaliação da capacidade antioxidante observada pelo método de DPPH obteve valores de $24,90 \mu \mathrm{mol}$ ET.g-1

Palavras-chave: melancia, carotenoides, DPPH.

\section{Introdução}

A melancia é um fruto pertencente à família das curcubitaceas e nativa da África. O Brasil se apresenta como o quarto maior produtor mundial de melancia, e, a cultura deste fruto é a sétima maior do país. Existem diversas variedades de melancia que diferem de acordo com o tamanho, forma, cor da superfície externa e cor da polpa. Grande parte da melancia encontrada no mercado brasileiro possui a polpa com coloração vermelha, devido à presença do licopeno. Porém, existem melancias com polpa amarela, alaranjada e branca, em consequência da ausência de licopeno e a presença de outros carotenoides. A estes compostos bioativos é atribuído uma capacidade antioxidante, capaz de promover efeitos benéficos à saúde. Tal característica justifica e estimula - estudo da melancia de polpa amarela, podendo apontar este fruto como uma possível nova fonte de carotenoides.

\section{Resultados e Discussão}

Foram adquiridos frutos de melancia amarela do estado da Bahia, os quais foram higienizados, despolpados e homogeneizados. Em seguida, uma fração da polpa de melancia amarela foi congelada para posteriores liofilização e otimização. A otimização da extração sólidolíquido foi realizada em banho, com agitação controlada. Primeiramente, realizou-se um planejamento inicial do tipo Plackett \& Burman para seleção das faixas significativas, utilizando como variáveis independentes: tempo de extração, temperatura de extração, concentração de etanol, volume de solvente. Posteriormente foi realizado um planejamento Delineamento Composto Central Rotacional (DCCR), sendo avaliadas como variável independentes a temperatura de extração, concentração de etanol e volume de solução, baseado em experimentos que avaliavam a cinética de extração, para encontrar o ponto otimizado. Para garantir a veracidade das informações encontradas no planejamento de DCCR, com os dados obtidos foi realizada a validação dos resultados, obtendo-se valores que variaram de 5,25 a $37,49 \mu \mathrm{g} / \mathrm{g}$. O estudo realizado, com avaliação da cinética de extração, indicou que menores tempos proporcionam maiores concentrações, o que pode ser justificado por uma menor exposição dos extratos. A superfície de resposta, exposta na Figura 1, confirma que, nas condições de maiores volumes de solução de extração e maiores concentrações de etanol tem-se maior extração dos carotenoides.

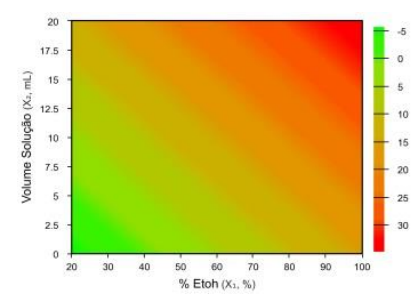

Figura 1. Superfície de resposta do planejamento tipo DCCR

Os carotenoides, devido a sua polaridade, são solúveis em solventes orgânicos. E, maiores volumes de solução extratora permitem uma extração exaustiva dos componentes de interesse, justificando o comportamento da curva de resposta, onde maiores concentrações de etanol e maiores volumes de solução apresentam maiores concentração de carotenoides em seus extratos. Com o extrato obtido, a partir das condições estabelecidas no ponto ótimo pelo planejamento experimental e pela validação, realizou-se a determinação de capacidade antioxidante utilizando a metodologia que avalia a redução do radical livre DPPH, obtendo-se valores de 24,90 $\mu \mathrm{mol}$ ET. $\mathrm{g}^{-1}$.

\section{Conclusões}

O presente estudo estabeleceu condições otimizadas para a extração de carotenoides totais presentes em melancia de polpa amarela. Os estudos indicaram que, maiores concentrações de metanol e menores tempos de exposição dos extratos proporcionam extratos com maiores teores de carotenoides totais e com capacidade antioxidante significativa.

\section{Agradecimentos}

Ao CNPq pela concessão da bolsa de iniciação científica da quota 2018-2019. 